\title{
IDENTIFIKASI JAMUR PADA BUAH NENAS (Ananas comosus L.) KULTIVAR MD2 PADA BERBAGAI TINGKAT KEMASAKAN
}

\author{
Rudianto Butarbutar', Suskandini Ratih ${ }^{2}$, Muhammad Nurdin², Radix Suharjo ${ }^{2}$ \\ ${ }^{1}$ Mahasiswa dan ${ }^{2}$ Dosen Jurusan Agroteknologi Fakultas Pertanian Universitas Lampung, Jl. Prof Soemantri Brodjonegoro \\ No. 1 Bandar Lampung 35143 \\ (Email: butarbutarrudianto@gmail.com)
}

\begin{abstract}
ABSTRAK
Nenas (Ananas comosus) merupakan salah satu komoditas yang dikembangkan di provinsi Lampung. Jenis nenasyang dikembangkan di Lampung diantaranya adalah kultivar MD2. Tingkat kemasakan buah ketika dipanen akan mempengaruhi mutu buah.Tingkat kemasakan buah nenas yang biasa digunakan untuk standar panen adalah stadium kacang hijau atau $<10 \%$, masak $10-15 \%$, dan masak $25 \%$. Diindikasikan terdapat kaitan antara tingkat kemasakan buah nenas dengan inten sitas serangan patogen. Penyakit pasca panen hingga kini belum mendapat perhatian yang memadai di negara berkembang kehilangan hasil pasca panen mencapai $50 \%$ atau lebih. Tujuan dari penelitian ini adalah untuk mengidentifikasi jamur-jamur yang terdapat pada buah nenas dengan tingkat kemasakan $<10 \%, 10-15 \%, 25 \%$ dan $>75 \%$. Pengambilan sampel buah nenas dilakukan di PT. NTF Lampung. Selanjutnya isolasi dan pengamatan mikroskopik patogen dilaksanakan di Laboratorium Proteksi Tanaman, Jurusan Agroteknologi, Fakultas Pertanian, Universitas Lampung. Penelitian dilaksanakan bulan Agustus 2015 - Oktober 2015.Hasil penelitian menunjukkan terdapatnya jenis jamur yang berbeda pada tingkat kemasakan nenas berturutan adalah tingkat kematangan $<10 \%$ yaitu Aspergillus sp., Penicillium sp, Trichoderma sp., tingkat kematangan 10-15\% yaitu Aspergillus sp., Penicillium sp., Trichoderma sp., tingkat kematangan 25\% yaitu Aspergillus sp., Penicillium sp., Trichoderma sp dan jamur Curvularia sp serta tingkat kematangan 75100\% yaitu Aspergillus sp., Penicillium sp., Fusarium sp.dan Curvularia sp.Curvularia sp. sudah termasuk kedalam jamur pasca panen tanaman nenas dimana sebelumnya hanya terdapat pada pertanaman nenas saja.
\end{abstract}

Kata kunci : Nenas, pasca panen, jamur, identifikasi, Aspergillus sp., Penicillium sp., Trichoderma sp., Fusarium sp.dan Curvularia sp.

\section{PENDAHULUAN}

Nenas (Ananas comosus) merupakan salah satu komoditas hortikultura penting yang dikembangkan di provinsi Lampung. Minat konsumen terhadap buah nenas segar cukup tinggi. Jenis nenas yang dikembangkan di Lampung diantaranyaadalah kultivar
MD2 yang biasa disebut oleh masyarakat sebagai nenas madu dengan keunggulan rasanya yang manis dan tidak menyebabkan gatal di lidah ketika dikonsumsi.

Menurut Hasbi et al (2005), tingkat kemasakan buah ketika dipanen akan mempengaruhi mutu buah. Buah yang dipanen terlalu cepat akan 
memiliki mutu buah yang tidak baik dan buah yang dipanen terlalu lama akan meningkatkan laju kerusakan pada buah. Tingkat kemasakan buah nenas yang biasa digunakan untuk standar panen adalah stadium kacang hijau atau $<10 \%$, masak $10-15 \%$, dan masak $25 \%$. Diindikasikan terdapat kaitan antara tingkat kemasakan buah nenas dengan intensitas serangan patogen. Menurut Semangun (2004), jamur yang pada umunya berasosiasi dengan buah nenas adalahThielaviopsis paradoxa, Penicillium sp., Fusarium sp. dan Cladosporium sp.

Buah yang telah dipanen sebenarnya telah mengandung berbagai mikroorganisme dari yang tidak menyebabkan pembusukan buah hingga yang menyebabkan pembusukan buah. Menurut Utama (2001) dalam makalah yang ditulis oleh Anna Rakhmawati tahun 2013, buah yang mengandung air dalam jumlah yang banyak sangat baik bagi pertumbuhan mikroorganisme. Mikrorganisme yang bersifat patogen yang menyerang buah pasca panen biasanya disebabkan oleh bakteri dan jamur. Infeksi awal dapat terjadi selama pertumbuhan dan perkembangan buah dilapangan namun mikroorganisme tersebut tidak tumbuh dan berkembang, hanya berada di dalam jaringan tanaman. Jika kondisi lingkungan memungkinkan mikroorganisme berkembang maka akan terjadi pembusukan pada masa penyimpanan buah.

Pada komoditas hortikultura, penyakit pasca panen hingga kini belum mendapat perhatian yang memadai. Penelitian di Amerika Serikat, menyatakan bahwa produk hortikultura yang telah dipanen terbuang percuma sebanyak $24 \%$ dari hasil panen (Wilson et a.l, 1994 dalam Suhardi,2009). Namun di negara berkembang kehilangan hasil pasca panen mencapai $50 \%$ atau lebih. Hal ini dikarenakan fasilitas penangan pasca panen masih sangat minim (Suhardi, 2009).

Untuk mengurangi intensitas serangan patogen buah pasca panen biasanya dilakukan pencucian buah namun pencucian buah tidak menghilangkan semua mikroorganisme pada buah. Menurut Sapers (2001), pencucian dan sanitasi buah secara konvensional tidak menghilangkan mikroorganisme patogen lebih dari 90\%. Hal ini dikarenakan respon mikroorganisme dalam tingkat penyerangan dipengaruhi oleh kondisi lingkungan.Tujuan dari penelitian ini adalah untuk mengidentifikasijamur-jamur yang terdapat pada buah nenas dengan tingkat kemasakan $<10 \%, 10-15 \%$, $25 \%$ dan $>75 \%$.

\section{METODE PENELITIAN}

Pengambilan sampel buah nenas dilakukan di PT. NTF Lampung. Selanjutnya isolasi dan pengamatan mikroskopik patogen dilaksanakan di Laboratorium Penyakit Tanaman, Jurusan Agroteknologi, Fakultas Pertanian, Universitas Lampung. Penelitian dilaksanakan bulan Agustus 2015 - Oktober 2015.

Alat - alat yang digunakan dalam penelitian ini yaitu gelas ukur, cawan petri, Beaker glass, Erlenmeyer, kaca objek, kaca penutup, mikroskop, buku identifikasi Alexopoulos and Mims(1979), autoklaf, jarum ose, bunsen, tabung reaksi, LAF (Laminar Air Flow), mikro pipet, kertas tissue. 
Bahan-bahan yang digunakan dalam penelitian ini antara lain buah nenaskultivar MD2 kemasakan tingkat kacang ijo atau $<10 \%$, kemasakan tingkat $25 \%$, keamasakan tingkat $75 \%$ dan kemasakan tingkat 100\%., air hasil mencuci buah nenas kultivar MD2 yang telah disebutkanyang dilakukan langsung di PT.NTF. Selain itu digunakan juga alkohol 70\%, Media PSA (Potato Succrose Agar) yang ditambah dengan rosebengal dan aquades.

Penelitian ini terdiri atas beberapa tahapan. Tahap pertama yaitu pengambilan sampel air cucian buah nenas yang disajikan di PT. NTF yang kemudian digunakan untuk diisolasi dan pengambilan sampel buah nenas PT. NTF. Tahap kedua yaitu isolasi air cucuian buah nenas yang berasal dari masing-masing tingkat kemasakan yang disajikan. Tahap keempat yaitu pengamatan isolat mulai hari ketiga hingga hari ketujuh. Tahap kelima pengamatan dengan menggunakan mikroskop yang kemudian gambar diambil dengan menggunakan kamera. Tahap keenam identifikasi jamur berdasarkan buku panduan identifikasi Alexopoulos and Mims(1979). Tahap ketujuh pemurnian isolat jamur yang telah diketahui identitasnya

\section{HASIL DAN PEMBHASAN}

Hasil isolasi air cucian nenas dengan empat tingkat kemasakan buah nenas yang berbeda yaitu Aspergillus sp., Curvularia sp., Fusarium sp., Penicillium sp., Trichoderma sp.

Aspergillus sp.

Secara makroskopis menurut Jawetz, et al (1996), Aspergillus sp. yang ditumbuhkan pada media SGA(Saboraud Dextrose Agar) ditambah dengan antibiotik, dapat tumbuh dengan cepat pada suhu ruang $37^{\circ} \mathrm{C}-40^{\circ} \mathrm{C}$. Koloni Aspergillus sp granular berserabut dengan beberapa warna sebagai salah satu ciri identifikasi. Aspergillus niger dengan koloni berwarna hitam, Aspergillus flavus dengan koloni berwarna kuning kehijauan dan Aspergillus fumigatus koloni dengan koloni berwarna hijau tua. Secara mikroskopis, Aspergillus sp. memiliki hifa bersekat dan bercabang. Pada bagian ujung hifa terutama bagian yang tegak membesar merupakan konidiofornya. Konidiofor pada bagian ujungnya membulat membentuk vesikel. Pada vesikel terdapat batang pendek yang disebut dengan sterigmata.

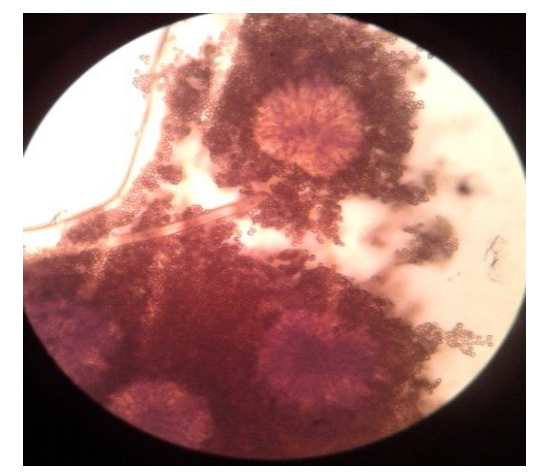

Gambar 1. Konidia Aspergillus sp. 
Sterigmata atau fialid berwarna atau tidak berwarna sebagai tempat tumbuh konidia yang membentuk rantai berwarna hijau, coklat atau hitam. Untuk membedakan spesies berdasarkan perbedaan warna konidia. (Makfoeld, 1993)

\section{Curvularia sp.}

Secara makroskopik, mula mula koloni berwarna putih, umur 3 hari mulai coklat kehitaman dan dihari kelima mulai berwarna hitam. Curvularia $s p$. mempunyai warna koloni coklat dan mirip beludru atau kapas. Konidiofor berbentuk tunggal atau berkelompok, tampak sederhana, lurus atau membengkok, berwarna coklat, memiliki panjang 600 ìm dan lebar 5-9 ìm pada bagian basis. Konidia bersepta empat, umumnya membengkok pada bagian sel yang paling lebar dan paling coklat, sel-sel yang ada di ujung berwarna lebih hialin dan berukuran (18-

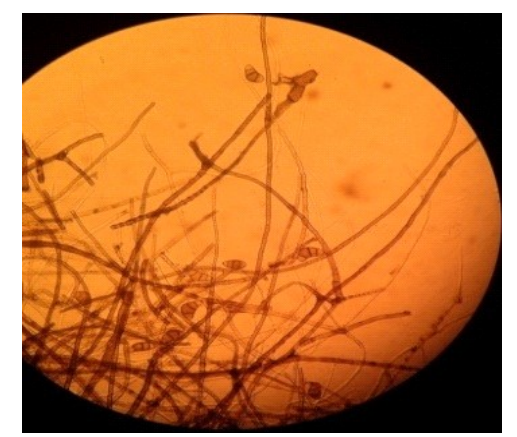

Gambar 2. Konidia Curvularia sp.

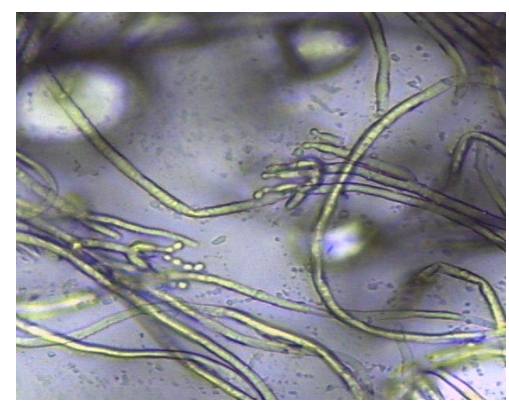

Gambar 4. Konidia Penicillium sp. 37)x(8-14 ìm) (Gandjar et al., 2006). Jamur dari spesies ini bersifat merugikan bagi tanaman dan belum diketahui apakah memiliki perananan positif bagi tanaman ataupun manusia.

\section{Fusarium sp.}

Fusarium sp. memiliki makrokonidium dan mikrokonidium yang berbentuk melengkung, panjang dengan ujung yang mengecil dan mempunyai satu atau tiga buah sekat, sedangkan mikrokonidium berukuran lebih kecil dari makroonidium dengan bentuk tidak bersekat atau bersekat satu dan dihasilkan oleh sporodokium. Miselia Fusarium sp. bersepta, bercabang cabang dan hialin, pada umur lanjut berwarna pink. (Semangun, 2000).

\section{Penicillium sp.}

Secara makroskopis, ciri-ciri yang dapat dilihat

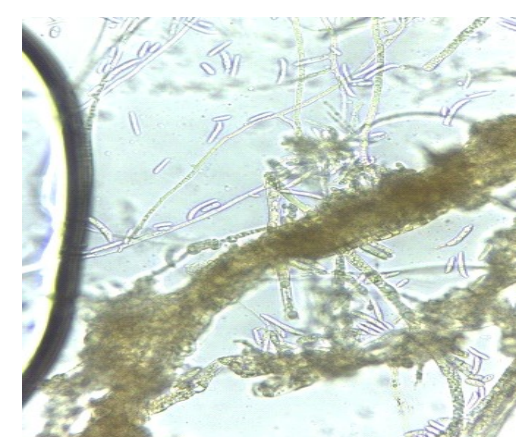

Gambar 3. Konidia Fusarium sp.

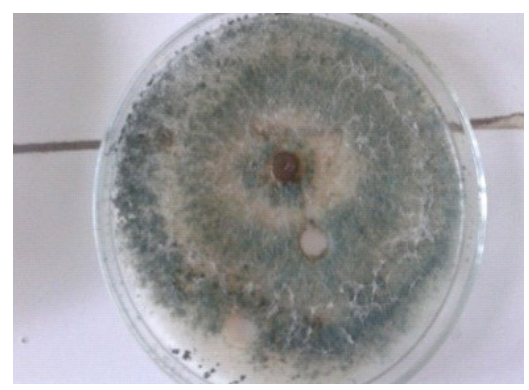

Gambar 5. Isolat Trichoderma sp 
yaitu koloni berwarna putih kemudian akan berubah menjadi agak kehijauan. Penicillium sp. mempunyai ciri-ciri spesifik yaitu; hifa berseptat, memilki miselium bercabang biasanya tidak berwarna. Konidiofor dari Penicillium berseptat dan muncul di atas permukaan yang berasal dari hifa bawah permukaan, dan bercabang atau tidak bercabang (Pohan, 2009). Ujung tangkai pendukung spora berbentuk seperti sapu dengan sterigmata atau fialida muncul dalam kelompok. Konidia pada waktu masih muda berwarna hijau, kemudian berubah menjadi kebiruan atau kecoklatan dan membentuk rantai karena muncul satu persatu dari sterigmata (Srikandi, 1992).

\section{Trichoderma sp.}

Koloni pada medium semula berwarna hialin, kemudian menjadi putih kehijauan dan selanjutnya hijau redup terutama pada bagian yang menunjukkan banyak terdapat konidia. Sebaliknya koloni tidak berwarna. Konidiofor dapat bercabang menyerupai piramida, yaitu pada bagian bawah cabang lateral yang berulang ulang, sedangkan kearah ujung percabangan menjadi bertambah pendek. Fialid tampak langsing dan panjang terutama pada apex dari cabang, dan berukuran $18 \mathrm{x}$ 2,5 ìm. Konidia berbentuk semi bulat hingga oval pendek, berukuran $(2,8-3,2) \times(2,5-2,8) \mathrm{m}$, dan berdinding halus. Klamidospora umumnya ditemukan dalam miselia dari koloni yang sudah tua, terletak interkalar dan kadang-kadang terminal, umumnya berbentuk bulat, berwarna hialin, dan berdinding halus (Gandjar et al., 2000).

\section{Pembahasan}

Hasil penelitian menunjukkan bahwa terdapat jamur-jamur dari hasil isolasi air pencuciannenaskultivar MD2 yaitu ; Aspergillus sp., Curvularia sp., Fusarium sp., Penicillium sp.dan Trichoderma sp. Dari tabel satu, dua, tiga, dan empat, tingkat kemasakan buah nenas mempengaruhi keragaman atau jenis jamur yang muncul selama periode inkubasi

Tabel 1. Tingkat Kemasakan Kacang Hijau (<10\%) (KI)

\begin{tabular}{cccccc}
\hline $\begin{array}{c}\text { Masa } \\
\text { inkubasi }\end{array}$ & \multicolumn{5}{c}{ Jenis Jamur } \\
\cline { 2 - 6 } & Aspergillus sp. & Curvularia sp. & Fusarium sp. & Penicillium sp. & Trichoderma sp. \\
\hline $\mathbf{3}$ & $\sqrt{ }$ & - & - & $\sqrt{ }$ & $\sqrt{ }$ \\
$\mathbf{5}$ & $\sqrt{ }$ & - & - & $\sqrt{ }$ & $\sqrt{ }$ \\
$\mathbf{7}$ & $\sqrt{ }$ & - & - & $\sqrt{ }$ \\
\hline
\end{tabular}

Tabel 2. Tingkat Kemasakan 10\%-15\%

\begin{tabular}{cccccc}
\hline Masa & \multicolumn{5}{c}{ Jenis Jamur } \\
\cline { 2 - 6 } inkubasi & Aspergillus sp. & Curvularia sp. & Fusarium sp. & Penicillium sp. & Trichoderma sp. \\
\hline $\mathbf{3}$ & $\sqrt{ }$ & - & - & $\sqrt{ }$ & $\sqrt{ }$ \\
$\mathbf{5}$ & $\sqrt{ }$ & - & - & $\sqrt{ }$ & $\sqrt{ }$ \\
$\mathbf{7}$ & $\sqrt{ }$ & - & - & $\sqrt{ }$ \\
\hline
\end{tabular}


3-7 hari. Pada kemasakan nenas tingkat kacang ijo atau dibawah $10 \%$ terdapat tiga jenis jamur yaitu Aspergillus sp., Penicillium sp, Trichoderma sp. Pada kemasakan nenas tingkat $10-15 \%$ juga terdapat tiga jenis jamur yaitu Aspergillus sp., Penicillium sp., Trichoderma sp., sedangkan kemasakan tingkat 25\% terdapat empat jenis jamur yaitu Aspergillus sp., Penicillium sp., Trichoderma sp. dan jamur Curvularia sp. Pada kemasakan tingkat 75-100\% terdapat empat jenis jamur yaitu Aspergillus sp., Penicillium sp., Fusarium sp.dan Curvularia sp.

Curvularia sp. merupakan jamur yang menyerang tanaman nenas dengan gejala berupa lepuh daun. Namun ternyata jamur jenis ini menginfeksi hingga ke bagian buah dengan gejala berupa pembusukan buah. Telah dinyatakan oleh Ferreira et al (2014) bahwa Curvularia sp. ternyata termasuk ke dalam jamur pasca panen nenas walaupun sebelumnya hanya diketahui menyerang nenas di pertanaman. Di Malaysia dilaporkan bahwa sejumlah jamur dapat menyebabkan bercak daun tanaman nenas, yaitu Curvularia lunata (Wakk) Boed., Curvularia muculans (Bancroft) Boed. Selain itu hawar daun disebabkan oleh Curvularia eragrositidis (P.Henn) J.A. Meyer.

Ternyata buah nenas dapat menjadi busuk karena pengaruh beberapa jamur antara lain Curvularia, Fusarium, Penicillium dan Cladosporium (Graham, 1971 dalam Semangun, 2004). Di Malaysia juga dilaporkan bahwa Penicillium funicolosum menyebabkan cork spot dan fruit core rot pada buah nenas. Selain itu disebutkan oleh Lim (1983 dalam Semangun 2004) juga bahwa cork spot disebabkan oleh Fusarium moniliforme, Ceratocytis paradoxa, dan Trichoderma sp.Jika buah yang sakit dibelah, maka akan tampak bagian yang berwarna coklat kemerahan atau hitam yang mengeras meluas mulai dari pusat buah (fruit core). Bagian berwarna coklat tersebut tidak berbau. Jamur-jamur tersebut dikenal sebagai parasit lemah, berkembang pada bagian

Tabel 3. Tingkat Kemasakan 25\%

\begin{tabular}{|c|c|c|c|c|c|}
\hline \multirow{2}{*}{$\begin{array}{c}\text { Masa } \\
\text { inkubasi } \\
3\end{array}$} & \multicolumn{5}{|c|}{ Jenis Jamur } \\
\hline & $\underset{\sqrt{ }}{\text { Aspergillus sp. }}$ & $\underset{\sqrt{ }}{\text { Curvularia sp. }}$ & $\begin{array}{c}\text { Fusarium sp. } \\
-\end{array}$ & $\underset{\sqrt{ }}{\text { Penicillium } \mathrm{sp} .}$ & Trichoderma sp. \\
\hline 5 & $\sqrt{ }$ & $\sqrt{ }$ & - & $\sqrt{ }$ & $\sqrt{ }$ \\
\hline 7 & $\sqrt{ }$ & $\sqrt{ }$ & - & $\sqrt{ }$ & $\sqrt{ }$ \\
\hline
\end{tabular}

Tabel 4. Tingkat Kemasakan 75\%-100\%

\begin{tabular}{cccccc}
\hline Masa & \multicolumn{5}{c}{ Jenis Jamur } \\
\cline { 2 - 6 } inkubasi & Aspergillus sp. & Curvularia sp. & Fusarium sp. & Penicillium sp. & Trichoderma sp. \\
$\mathbf{3}$ & $\sqrt{ }$ & $\sqrt{ }$ & $\sqrt{ }$ & $\sqrt{ }$ & - \\
$\mathbf{5}$ & $\sqrt{ }$ & $\sqrt{ }$ & $\sqrt{ }$ & $\sqrt{ }$ & - \\
$\mathbf{7}$ & $\sqrt{ }$ & $\sqrt{ }$ & $\sqrt{ }$ & $\sqrt{ }$ & - \\
\hline
\end{tabular}


bunga yang telah mati dan masuk dalam buah.

Kematangan atau kemasakan buah merupakan suatu proses perubahan yang terjadi pada buah meliputi perubahan warna, tekstur, rasa, dan kualitas. Pematangan atau pemasakan buah memiliki hubungan yang erat dengan perubahan pati menjadi gula (Satuhu, 2007). Hal ini dapat dilihat pada buah mentah yang secara umum dikenal dengan karakteristik berwarna hijau, tekstur keras, rasa masam dan tidak berasa sama sekali seperti tepung yang tawar, aromanya sedikit atau tanpa aroma. Selama pematangan buah terjadi perubahan dalam berbagai segi termasuk proses biokimia yang terjadi di dalamnya (Abidin, 1991). Pelunakan buah terjadi karena adanya hidrolisis poliskarida pada dinding sel, termasuk juga terhidrolisisnya protopektin menjadi pektin yang larut sehingga daya rekat antar sel berkurang dan buah menjadi lunak (Eskin et al., 1971). Pektin yang terkandung pada buah merupakan zat yang mudah terhidrolisis menjadi komponen-komponen yang larut air sehingga total zat pektin akan menurun kadarnya dan komponen yang larut air akan meningkat jumlahnya mengakibatkan buah menjadi lunak (Muchtadi, 2010).

Selain berbentuk pektin, karbohidrat pada buah juga terdapat dalam bentuk pati. Perubahan karbohidrat terjadi selama pemasakan buah. Pada buah muda, karbohidrat masih banyak dalam bentuk pati sehingga rasa buah tidak manis. Selama proses pematangan buah, melalui reaksi enzimatis, pati akan dipecah menjadi gula sederhana seperti glukosa, fruktosa dan sukrosa sehingga buah menjadi manis.
Buah akan menjadi lebih manis setelah asam organik atau molekul pati diubah menjadi gula yang bisa mencapai konsentrasi $20 \%$ pada buah matang (Campbell et al., 1999).

Proses pematangan pada buah sangat berhubungan dengan perubahan warna, membran permeabilitas, kandungan hormon, produksi uap, pola respirasi, dan pelembutan dinding sel. Sifat pematangan buah ditentukan dengan melihat pola respirasi pada buah. Pola tersebut yang membedakan antara buah klimakterik dan buah non klimakterik (Satuhu, 2007).

\section{KESIMPULAN}

Berdasarkanhasil penelitian yang telah dilakukan, maka diperoleh kesimpulan sebagai berikut: Terdapatnya jenis jamur yang berbeda pada tingkat kemasakan nenas berturutan adalah tingkat kematangan $<10 \%$ yaitu Aspergillus sp., Penicillium sp, Trichoderma sp., tingkat kematangan 10-15\% yaitu Aspergillus sp., Penicillium sp.,Trichoderma sp., tingkat kematangan 25\% yaitu Aspergillus sp., Penicillium sp., Trichoderma sp dan jamur Curvularia sp serta tingkat kematangan $75-100 \%$ yaitu Aspergillus sp., Penicillium sp., Fusarium sp.dan Curvularia sp.Curvularia sp. sudah termasuk kedalam jamur pasca panen tanaman nenas dimana sebelumnya hanya terdapat pada pertanaman nenas saja. 


\section{DAFTAR PUSTAKA}

Abidin, Z. 1991. Dasar-dasar Pengetahuan Ilmu Tanaman. Angkasa. Bandung. 177 hal.

Alexopoulos, C.J. and C.W. Mims. 1979. Introductory Mycology. John Wiley \& Sons. New Yorks.

Campbell, N.A., J.B. Reece, and L.G. Mitchel. 1999. Biology. Fifth Edition. Addison Wesley Longman. USA. 681 hal.

Eskin, N.A.M., H.M. Henderson and R.L.Townseed. 1971. Biochemistry of Food. Academic Press. New York. 541 hal.

Ferreira A. P. S, D. B. Pinho, A.R. Machado, and O.L. Pereira. 2014. First Report of Curvularia eragrostidis Causing Postharvests Rot on Pinneapple in Brazil. Phitopatologia Department in Federal de Vicosa University. Vicosa. Minas Gerais. Brazil.

Gandjar, Indrawati dan S. Wellyzar. 2006. Mikologi Dasar dan Terapan. Jakarta: Yayasan Obor Indonesia. 238 hal.

Hasbi, D. Saputra, dan Juniar. 2005. Masa simpan buah manggis (Garcinia mangostana L.) pada berbagai tingkat kematangan, suhu dan jenis kemasan. Jurnal Teknologi dan Industri Pangan. 16(3): 199 - 205.

Jawetz, E., J. L. Melnick, and Adelberg E. A. 1996.Mikrobiologi Kedokteran, Edisi ke-20, 213, EGC, Penerbit Buku Kedokteran, Jakarta

Makfoeld, D. 1993. Mikotoksin Pangan. Yogyakarta. Kanisius. 211 hal.
Muchtadi, T. R. 2010. Ilmu Pengetahuan Bahan Pangan. Alfabeta. Bandung. 332 hal.

Price, S.A., dan L.M.Wilson. (1994). Patofisiologi: Konsep Klinis Proses-proses Penyakit. Edisi Keempat.. Jakarta: Buku Kedokteran EGC. Hal. 371-372, 376-378, 389-409.

Rakhmawati, A. 2013. Mikroorganisme Kontaminan Pada Buah. Biology FMIPA UNY. Yogyakarta. 9 hal.

Sapers, GM. 2001. Efficacy of washing and sanitizing methods for disinfection of fresh fruits and vegetables products. Food Technol. Biotechnol. 39(4). 305-311

Satuhu. 2007. Pisang Budidaya Pengolahan dan Prospek Pasar. Penebar Swadaya. Jakarta. 124 hal

Semangun, H., 2000. Penyakit - Penyakit Tanaman Perkebunan di Indonesia. Gadjah Mada University -Press, Yogyakarta, hal 11-30.

Semangun, H. 2004. Penyakit-Penyakit Tanaman Hortikultura di Indonesia. UGM Press. Yogyakarta. 2930. 850 hal.

Suhardi. 2009. Pengembangan Inovasi Pertanian. Cianjur: Balai Penelitian Tanaman Hias.hal 110130.

Srikandi, F. 1992. Polusi Air \& Udara. Penerbit Kanisius. Yogyakarta. 192 hal.

Utama, M.S. 2001. Penanganan Pascapanen Buah dan Sayuran Segar. Makalah "Forum Konsultasi Teknologi” Dinas Pertanian Tanaman Pangan Provinsi Bali. 